\title{
TOWARDS PROCESS MATURITY - TRIGGERS OF CHANGE
}

\author{
Arkadiusz Jurczuk \\ Faculty of Management, Bialystok University of Technology, Wiejska 45A, Bialystok, Poland \\ E-mail: a.jurczuk@pb.edu.pl
}

\begin{abstract}
Process-oriented development of an organization is supported by maturity models. They delineate a sequence of stages that together form a path from an initial to a desired maturity level. Maturity progress is determined by various success factors and initiated by different triggers. There is no common classification of these triggers. The purpose of this paper is to identify triggers in relation to maturity levels. To identify triggers a contextual model has been developed and literature review has been conducted. Results suggest that due to incomplete understanding of process-based approach some additional triggers may also affect success of its implementation.
\end{abstract}

Keywords: organisation, process, maturity, triggers and drivers.

JEL Classification: L29; M19.

\section{Introduction}

In today's market environment, business process orientation is considered to be an attractive and effective way of building competitive advantage of organizations. This approach is becoming well adapted paradigm of organizational improvement and development. The interest in process-based approach results from the intention of the organization to improve its flexibility in adapting to changes in the new business environment, market expectations and customers needs (Zairi 1997; Willaert et al. 2007; Dallavalle de Pádua et al. 2014).

One of the important approaches increasing process-based orientation of an organisation is Business Process Management (BPM). BPM is a complex management practice including diverse and myriad methods, frameworks aimed at improving the organization processes and achieving the desired level of maturity (Škrinjar, Trkman 2013). The implementation of BPM is mainly triggered by too high costs, problems with quality, low profitability, competitiveness (Davenport, Short 1990; Pritchard, Armistead 1999; Jeston, Nelis 2008, Alves et al. 2014).

The main purpose of this paper is to provide a research of triggers and drivers of maturity progress in context of critical success factors. The results of the research allowed to identify and systematized these triggers concerning maturity levels. In addition, the contextual model with postassessment triggers which was based on the results of the literature review perspective has been proposed.

\section{Process orientation and process maturity}

Davenport and Short (1990), Hammer and Champy (1993) belong to the first promoters of the "process orientation" and "process-thinking" concept. The idea of the "horizontal cooperation/organization" was furthermore developed by Byrne (1993) and Ostrof (1997). According to McCormack and Johnson (2001) "business process orientation of an organisation is the level at which an organisation pays attention to its relevant (core) processes". The subsequent empirical research conducted i.a. by McCormack (2001) confirmed that the process orientation can positively influence organizational performance and inter-functional conflicts.

McCormack (2001) has distinguished three elements that affect the process-driven transformation of an organization: the process management and measurement, the process jobs (process business roles) and the complex process view (documentation and understanding of processes). The essential feature of this approach is the cooperation and coordination of tasks at different levels of decision-making and in a various functional departments and organizational units. Due to the process-based approach it is possible to gain knowledge about the situation and efficiency of the entire organization. Additionally, process orientation enables to define the scope of changes that allow the company to adapt to future market conditions (McCormack, Johnson 2001). Rosemann et al. (2008) indicate that the level of maturity of the process-oriented organization affects six factors: 
Strategic Alignment, Culture, People, Methods, Governance and Information Technology. Lee and Dale (1998) emphasise that process approach involves linking business processes and strategic objectives and needs of customers. It requires also a change in a company's emphasis from functional (vertical, hierarchical) to process orientation (horizontal, cross-functional). We can consider the transformation of an organization, from a vertical to horizontal one, as maturing process - structured and formalized, with specific stages (maturity levels) (Rosemann et al. 2008; Karagiannis 2013).

BPM maturity refers to the stages which an organization striving to achieve their goals passes through. The maturity level is the "degree of process improvement across a predefined set of process areas in which all goals in the set are attained" (van Looy et al. 2011; Zellner 2011). Maturity evolution of on organization is supported by various organisational and process maturity models. Among the various methods that support building a process-oriented organization, maturity models meet with a growing interest (Röglinger et al. 2012; Scheel et al. 2015; Tarhan et al. 2016).

The development of maturity models has been initiated by the Capability Maturity Model (CMM) (Humphrey 1988). Primarily CMM was designed mainly to support IT enterprise in the assessment of their capabilities and to identify areas of improvement. The key maturity models stemming this trend should also include: Business Process Orientation Maturity Model (McCormack, Johnson 2001), Business Process Maturity Model (Object Management Group 2008). Maturity models include a sequence of stages that form an anticipated, desired or logical path from a current state to maturity (Röglinger et al. 2012; Wong et al. 2014).

The level of maturity of process organization is the range in which the processes are formally defined, managed, flexible, measured and effective (Rosemann et al. 2008). Maturity could be seen as an organization's ability to process excellence. Maturity is multidimensional. It should include both factors for process repeatability and resources, the ability to ensure such repeatability. A stage of organization's maturity is evaluated usually in four or five-point scale (McCormack, Johnson 2001; Object Management Group 2008). Maturity could be related to an area and/or a process. Level I (immature) of the enterprise is characterized as an uncoordinated and unstructured ad hoc operation and is identified with the silo structure. The processes at this stage are not designed in accordance with the "end-to-end" principle. While the level of full maturity means that the organization's processes are systematically improved, and these actions are a constant element of the organizational culture (Niehaves et al. 2014; von Scheel et al. 2015). Reaching the stage of full maturity is equated with the highest level of effectiveness and efficiency of the organization.

You can readily identify areas of potential improvement, resulting in achieving desired objectives by evaluating a current stage of organization by a maturity framework (Humphrey 1998). Change of a maturity level generally includes management systems (style, culture, measurement), human resources (organizational roles, skills, organizational culture), information technology and organizational structure, moreover depends on those factors (Pritchard, Armistead 1999; Bandara et al. 2009; Trkman 2010; Ravesteyn, Batenburg 2010). Success of BPM deployment and maturity progress depends on Critical Success Factors (CSFs). A change of maturity level is caused by external or/and internal triggers and drivers (Rosemann et al. 2008; Willaert et al. 2007; von Scheel et al. 2015).

\section{Methodology and context model of research}

Research objectives have been reached through literature studies and empirical survey that are systematically conducting by the author. To identify $\mathrm{BPO} / \mathrm{BPM}$ triggers I reviewed scientific papers published in journals and business reports related to this domain. This approach is widely used and accepted. Such methodology allows to specify the current state of research and to identify a research gap in the analyzed area (Tranfield et al. 2003).

Conducted literature review has revealed there are not many publications on the identification and classification of BPM triggers in the context of maturity level. Therefore research questions addressed in this paper are as follows:

RQ1. What kind of critical success factors affect a BPM implementation?

RQ2. What triggers and drivers initiate the progress of a process and organisation's maturity?

RQ3. What critical success factors affect a transition between maturity stages?

To answer these questions a research model has been constructed. This model presents a research perspective. The model illustrates the context of transformation of organisation towards the desired maturity level. Achieving a higher maturity level (stage) is initiated by external or/and internal triggers and determine by Critical Success Factors (CSFs). The contextual research model is given in the Figure 1. 


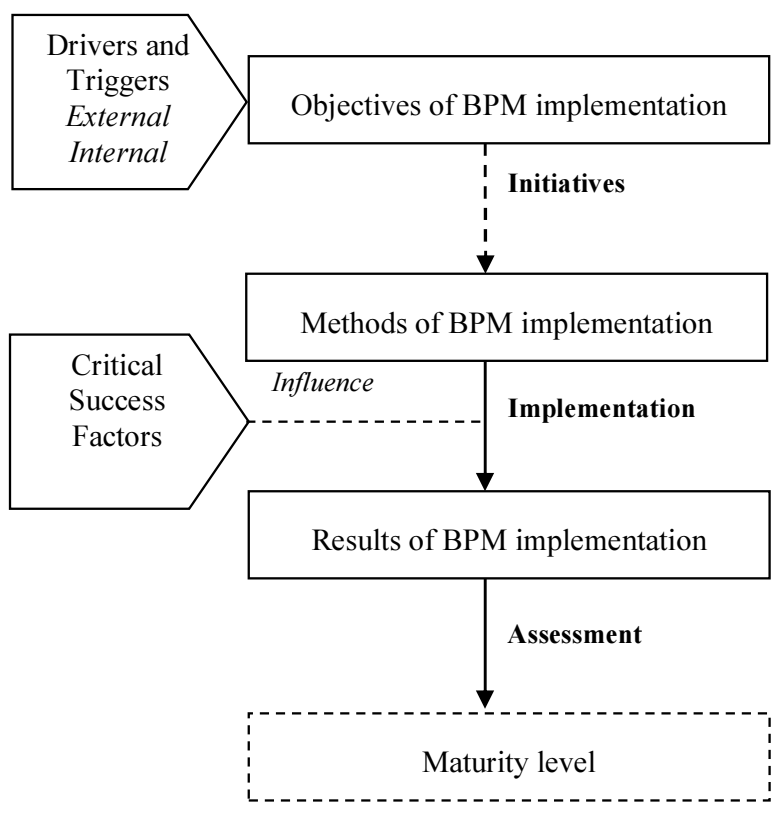

Fig. 1. Contextual model of research

(Source: developed on a basis of Safrudin et al. 2014)

External triggers represents changing market conditions, competitive threats, government regulations, customer demand and satisfaction, policy, regulatory and technological advancements. The internal ones are mainly connected with performance issues, leadership changes or looking for a new possibilities for a growth and expansion, changes in IT and organizational structure (Safrudin, Recker 2012). The result of BPM/BPO implementation depends on proper indentifying and analysis of Critical Success Factors (CSFs).

\section{Critical success factors of $B P O / B P M$ maturity}

Although a process-driven approach and methodology is widely known and it is very often implemented, the failure rate of BPO/BPM projects is relatively high (40-50\%) (Bai, Sarkis 2013; Iqbal et al. 2015). The causes of success/failure of BPM initiatives is called Critical Success Factors. These factors could be treated as a barrier, as well as an enabler (Santos et al. 2015). CSFs are defined by Bullen and Rockart (1981) as "the limited number of areas in which satisfactory results will ensure successful competitive performance for the individual, department or organization". CSFs are the few key areas for the organisations that enable development and attaining their goals.

Critical Success Factors should be identified and evaluated for reducing the failure rate of BPO/BPM implementation (Ariyachandra, Frolick 2008; Bandara et al. 2007; Buh et al. 2015). Conducted papers review allow to identify ten CSFs that determine the BPO/BPM initiative. Table 1 presents the results of general classification of critical success factors.

Table 1. Critical Success Factors (Source: Ariyachandra, Frolick 2008; Bai, Sarkis 2013; Bandara et al. 2009; Buh et al. 2015; Jeston, Nelis 2008; Trkman 2010)

\begin{tabular}{l|l}
\hline Critical Success Factor & Recommendations $\left.{ }^{*}\right)$ \\
\hline Strategic alignment & {$[1][2][3][4][5][6]$} \\
\hline Top management support & {$[1][2][3][4][5]$} \\
\hline Methodology & {$[1][3][4][5]$} \\
\hline Team domain competences & {$[1][2][3][4][5]$} \\
\hline Project management & {$[1][2][3][4][5]$} \\
\hline Culture & {$[1][2][3][4][5][6]$} \\
\hline Communication & {$[1][3][4]$} \\
\hline Empowerment & {$[3][4][5][6]$} \\
\hline Measurement and monitoring & {$[2][3][4][5][6]$} \\
\hline Information technology & {$[2][3][4][6]$} \\
\hline
\end{tabular}

Examining the results of literature review it could be concluded that the most dominant $\mathrm{BPO} / \mathrm{BPM}$ success factors are strategic alignment and culture. The organizational culture, particularly a willing to change determines a success of BPM implementation (Buh et al. 2015; Gonçalves 2010; Ravesteyn, Batenburg 2010). Ariyachandra and Frolick (2008) emphasize also a role of management of resistance and problems with resources availability (monetary, people, time). They also indicated that BPM project success is also affected by external customers/users. The main reason of failure of BPO/BPM initiatives could be a low understandability of linkages between success factors (Trkman 2010).

Boundary conditions of success of process improvement are determined by the ability to identify, assess and use of CSFs. The degree of fulfilment and understanding of critical success factors sets boundary conditions to improve business processes and achieve higher levels of organization's maturity.

\section{Triggers and drivers of BPO maturity}

Process-oriented development of organization can be triggered by many different initiatives. Karagiannis (2013) indicate mainly aspects related to implementing IT systems, workflow management systems and business applications (ERP, CRM, SRM system). Is also emphasized requirements of 
quality standards (ISO certification) and legal aspects, regulations (Sarbanes-Oxley Act, Basel III). The authors indicate moreover the triggers related to operational efficiency, costs reduction and improving product and service quality. According to Karagiannis (2013) changes in the organization are initiated by globalization, market's dynamic, requirements of information transfer and global standards, inter-organizational value chains and outsourcing. On the other hand, the need for changes in the organization because of the requirements of flexible IT architectures, mobile IT and new means of communication must be introduced. A more complex and structured classification of BPO/BPM triggers and drivers present Jeston and Nelis (2008). In Table 2 main outputs from their research are given.

The conducted literature review has revealed there are not many publications on the identification and classification of BPO/BPM triggers in context of a stage of a process/organisation's maturity. According to the author knowledge this issue is a part of the systematic research on organization maturity conducted mainly by Harmon (2007), Harmon, Wolf $(2014,2016)$. Maturity diagnosis prepared by BPTrends was based on Capability Maturity Model Integration (Harmon, Wolf 2014, 2016).

According to BPTrends cyclical report (Harmon, Wolf 2014) the major BPM driver during the period 2005-2013 was the "saving a money by reducing costs" and/or "low productivity." The second most important trigger, in 2013 was the "low customer satisfaction". The most important drivers also include "problem with management coordination or organizational responsiveness". The first two drivers, "a need to improve customer satisfaction to remain competitive" and a "need to save a money" were of such importance to the organization in 2015 (Harmon, Wolf 2016).

Another report describing maturity levels of organizations with maturity triggers was prepared by Kerremans (2008). In this research a Gartner's maturity model has been used. Table 3 presents simplified classification of triggers concerning levels of BPO/BPM maturity.

$\mathrm{BPO} / \mathrm{BPM}$ triggers and drivers definitely depend on various factors and should be considered in a specified context (economic, market, technology and industrial or organization's process maturity). Furthermore, the triggers are different for different enterprises and depend on the specific business and a social situation (Jeston, Nelis 2008).
Table 2. General classification of BPM triggers and drivers (Source: Jeston, Nelis 2008)

\begin{tabular}{|c|c|}
\hline Category & Triggers and drivers (chosen) \\
\hline Organization & $\begin{array}{l}\text { Difficulties with high growth or proac- } \\
\text { tive planning for high growth } \\
\text { Changing roles and responsibilities } \\
\text { Problems with operational excellence, } \\
\text { Necessity to change a product leader- } \\
\text { ship } \\
\text { Organization objectives or goals are } \\
\text { not being met }\end{array}$ \\
\hline Management & $\begin{array}{l}\text { Lack of reliable or conflicting man- } \\
\text { agement information } \\
\text { Lack of control over processes } \\
\text { Budget over deliver } \\
\text { Low capacity from existing staff for } \\
\text { expansion/development }\end{array}$ \\
\hline Employees & $\begin{array}{l}\text { High turnover of employees } \\
\text { Training issues with new employees } \\
\text { Low employee satisfaction } \\
\text { Problems with empowerment } \\
\text { Difficulties in keeping up with contin- } \\
\text { ues changes and growing complexity. }\end{array}$ \\
\hline $\begin{array}{l}\text { Customers } \\
\text { and } \\
\text { co-operators }\end{array}$ & $\begin{array}{l}\text { Long lead times to meet requests } \\
\text { Low satisfaction with service } \\
\text { Changes of numbers of customer, sup- } \\
\text { pliers or partners } \\
\text { The introduction a unique process for } \\
\text { customer or co-operators } \\
\text { The introduction and strict enforce- } \\
\text { ment of service levels }\end{array}$ \\
\hline $\begin{array}{l}\text { Products } \\
\text { and services }\end{array}$ & $\begin{array}{l}\text { Lack of business agility } \\
\text { Poor service levels } \\
\text { Problems with standardization } \\
\text { Launch a new product/service }\end{array}$ \\
\hline Processes & $\begin{array}{l}\text { Unclear roles and responsibilities from } \\
\text { a process perspective } \\
\text { Poor quality of the results and a sub- } \\
\text { stantial volume of rework } \\
\text { Too much gaps in a process } \\
\text { Lack of process standardization } \\
\text { Work duplication } \\
\text { Backlogs } \\
\text { Lack of clear process goals } \\
\text { Lack of communications } \\
\text { Lack of understanding of the end-to- } \\
\text { end process by stakeholders }\end{array}$ \\
\hline $\begin{array}{l}\text { Information } \\
\text { technology }\end{array}$ & $\begin{array}{l}\text { Problems with integration, utilization } \\
\text { of BPM automation tools } \\
\text { Introduction of a new IT architecture } \\
\text { Phasing out of old application } \\
\text { Problems with overlapping of existing } \\
\text { systems } \\
\text { The introduction of web services } \\
\text { IT cost are not accepted }\end{array}$ \\
\hline
\end{tabular}


Table 3. BPO/BPM triggers and drivers - maturity context (Source: Kerremans 2008; Harmon, Wolf 2014, 2016)

\begin{tabular}{|c|c|}
\hline $\begin{array}{l}\text { Maturity } \\
\text { level }\end{array}$ & $\mathrm{BPO} / \mathrm{BPM}$ triggers and drivers \\
\hline $\mathrm{I}$ & $\begin{array}{l}\text { Low productivity } \\
\text { Poor financial results }\end{array}$ \\
\hline II & $\begin{array}{l}\text { Problems with responsibility } \\
\text { Incomplete process documentation } \\
\text { The need of standardize common pro- } \\
\text { cesses throughout the organization } \\
\text { Necessity of improving existing pro- } \\
\text { cesses driven by strategic planning } \\
\text { Distributed information system }\end{array}$ \\
\hline III & $\begin{array}{l}\text { Difficulties with process visibility and } \\
\text { operational agility } \\
\text { The need to control and automate process- } \\
\text { es (including BPMS) } \\
\text { Necessity of building a relationships } \\
\text { between cross-functional processes }\end{array}$ \\
\hline IV & $\begin{array}{l}\text { Lack of well-established links and } \\
\text { relationships between cross-functional } \\
\text { processes (processes that cross bound- } \\
\text { aries, within the organization itself and } \\
\text { beyond) and with trading partners and } \\
\text { customers } \\
\text { Necessity of creating a network with } \\
\text { suppliers and customers } \\
\text { Problems with interprocess inefficiencies }\end{array}$ \\
\hline $\mathrm{V}$ & $\begin{array}{l}\text { Necessity of deployment systems for } \\
\text { a value chain control } \\
\text { Lack of coordination of partners and } \\
\text { customers goals }\end{array}$ \\
\hline
\end{tabular}

A low productivity and poor financial results are usually on the initial maturity level. Enterprises on the second level are already seeking to improve existing processes, starting with documenting and process modelling (process maps and flowcharts). The main triggers for further changes (level III, IV) is a necessity of process control and automation. At the highest levels of maturity of the company there is a need to define the relationships and dependencies between cross-functional processes and identifying and creating a relationships network with suppliers and customers. A process optimization level requires organizations to implement controls throughout the value chain, including business partners and customers (McCormack et al. 2009; Kerremans 2008; Harmon, Wolf 2014, 2016).

Jurczuk and Gabryelczyk (2015) also took an attempt to identify and classify BPM triggers. According to results of their research companies representing the lowest level of maturity are interested in building their competitive advantage mainly
Table 4. Triggers and drivers in Polish companies maturity context (Source: Jurczuk, Gabryelczyk 2015)

\begin{tabular}{c|l}
\hline $\begin{array}{c}\text { Maturity } \\
\text { level }\end{array}$ & \multicolumn{1}{c}{ BPM triggers and drivers } \\
\hline I & $\begin{array}{l}\text { Too high operation costs } \\
\text { Distributed information system - prob- } \\
\text { lems with information access }\end{array}$ \\
\hline II & $\begin{array}{l}\text { Necessity of improving a quality of a } \\
\text { customer service and too high costs of } \\
\text { this service } \\
\text { Incomplete process documentation } \\
\text { Problems in supporting processes }\end{array}$ \\
\hline III & $\begin{array}{l}\text { Management and control problems - } \\
\text { searching for a new alternative man- } \\
\text { agement methods and techniques } \\
\text { Problems in supporting processes }\end{array}$ \\
\hline
\end{tabular}

through reducing operating costs. It is one of two basic solutions, next to the implementation of IT systems and/or application. These two factors triggered a change in those companies and initiate an "entrance" to the second level of maturity (see Table 4).

Organization being on the second maturity level are interested in improving the quality of customer service while minimizing costs of operation. Additionally, streamlining document workflow and improving the functioning of the supporting processes. At this stage the company has suggested the problem or even the lack of ability to control the documents' flow, unsatisfactory accessibility to them, and too long time needed to locate a document. Organizations classified on the third level of maturity are interested in the introduction of new management methods and improvement of supporting processes. None of the companies investigated did not reach higher than the third level of BPM maturity (Jurczuk, Gabryelczyk 2015).

The common denominator of above mentioned problems is probably a lack of domain competencies (project and process management). Analysis of the results of the implementation of the BPM indicates problems with understanding the role of leadership and culture of change. A need to reduce cultural resistance to process change (Harmon, Wolf 2016) becoming an important driver causing an interest in the process-based approach. Those critical success factors in this case seem to be key barriers for the organisations to develop and to attain their business goals. According to Harmon (2007) there is a key problem to cross a "chasm" between level II and III, which is related to top management support. He indicates also that organisation moving on to the third stage get into "a process maturity gap". A similar problem with 
transition between the second and the third maturity level emphasise Nikolova-Alexieva (2013).

Preparation and implementation faults cloud be perceived as a post-assessment trigger. Taking into account observed problems of analysed companies with maturity progress the initial research model has been revised. Figure 2 presents a contextual research model that includes an affect of a post-assessment trigger.

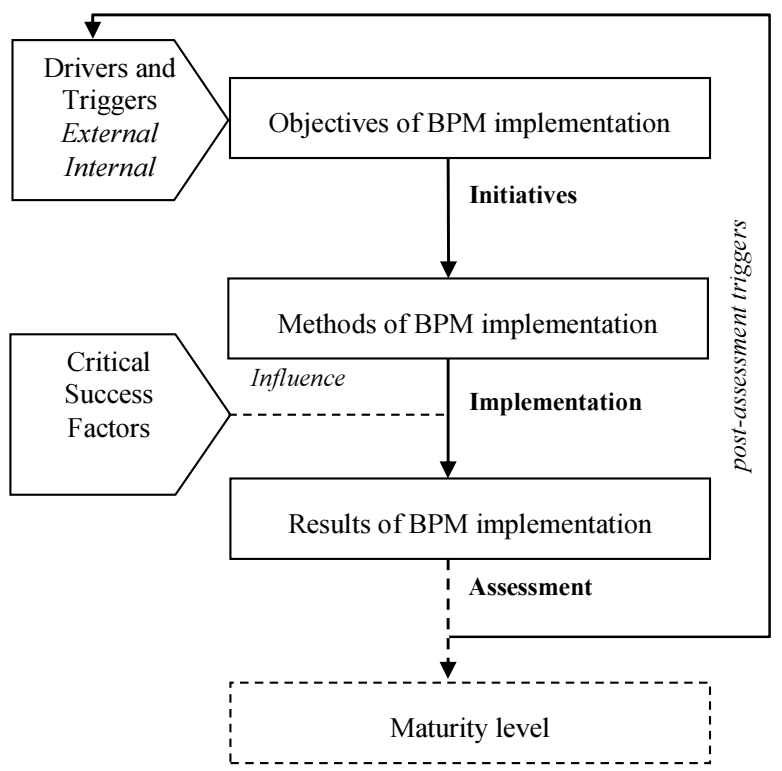

Fig. 2. Revised contextual model of research (Source: developed on a basis of Safrudin et al. 2014)

The post-assessment triggers are the result of process maturity evaluation in the organization. Their appearance may indicate incomplete understanding of the organization's objectives and requirements associated with achieving a certain level of maturity (Jurczuk, Gabryelczyk 2015). These problems can also result from incomplete understanding of BPM framework. The achieved results from this research reflect the specificity of the management problems in organization from transition countries (Warner et al. 2005).

It should be also underlined that the implementation of modern methodologies (TQM) sometimes is treated as a target in itself and not as a way to solve the existing problems (Westphal et al. 1997). Similar mechanism could be observed in BPM implementation in this case.

\section{Conclusions, limitation and future research}

Process-approach and continues improvement through evolutional changes became an abiding element of the organisational development. As a result of implementing process-driven methods companies still evolve achieving their goals. In the domain literature, there are numerous of studies of the BPO/BPM critical success factors and maturity models that present those problems from different perspective. But the survey on maturity triggers are rather rare.

This paper is only initial attempt to exploring maturity triggers. The conducted study allowed identified and systematized BPO/BPM triggers. Taking into account the conclusions from the Jurczuk and Gabryelczyk study (2015) is worth considering post-assessment triggers in the contextual research model. This model may reflect an incomplete understanding of the organization's objectives and requirements associated with of BPM implementation in organizations. An organisational culture, team domain competences and a top management support in this case can be considered the key barriers (CSFs) to the transition to a higher level of maturity (Harmon 2007; Malinova et al. 2014; Santos et al. 2015). Besides, introducing BPM methodologies may need to adapt them to the abilities, experience of users and specific conditions in which the organization operates (Filipowska et al. 2009; Pöppelbuß, Röglinger 2011).

The main limitations of this research is a small number of revised paper aiming at BPM maturity triggers. This initial study could be continued in the context of the contingency theory (Trkman 2010; Niehaves et al. 2014).

Identification and classification of triggers can be used to a more comprehensive diagnose of the a process-driven development of organizations. It may furthermore be useful for revising and adapting process maturity roadmaps.

\section{Disclosure statement}

I declare that I do not have any competing financial, professional, or personal interests from other parties.

\section{Funding}

The research were conducted within S/WZ/1/2014 project and were financed from Ministry of Science and Higher Education funds.

\section{References}

Alves, C.; Valença, G.; Santana, A. F. 2014. Understanding the factors that influence the adoption of BPM in two Brazilian public organizations, in I. Bider, K. Gaaloul, J. Krogstie, S. Nurcan, H. A. Proper, R. Schmidt, P. Soffer (Eds.). Enterprise, business-process and information systems modeling. Berlin-Heidelberg: Springer. 
Ariyachandra, T. R.; Frolick, M. N. 2008. Critical success factors in business performance management - striving for success, Information Systems Management 25: 113-120. http://dx.doi.org/10.1080/10580530801941504

Bai, Ch.; Sarkis, J. 2013. A grey-based DEMATEL model for evaluating business process management critical success factors, International Journal of Production Economics 146(1): 281-292. http://dx.doi.org/10.1016/j.ijpe.2013.07.011

Bandara, W.; Alibabaei, A.; Aghdasi, M. 2009. Means of achieving business process management success factors, in D. Drossos, K. Fouskas (Eds.). Proceedings of the $4^{\text {th }}$ Mediterranean Conference on Information Systems, 25-27 September 2009, Athens, Greece.

Bandara, W.; Indulska, M.; Chong, S.; Sadiq, S. 2007. Major issues in business process management: an expert perspective, in Proceedings of the $15^{\text {th }} \mathrm{Eu}$ ropean Conference on Information Systems, 7-9 June 2007, St Gallen, Switzerland. Available from Internet: http://aisel.aisnet.org/ecis2007/89/

Buh, B.; Kovačič, A.; Indihar Štemberger, M. 2015. Critical success factors for different stages of business process management adoption - a case study, Economic Research-Ekonomska Istraživanja, 28(1): 243-258. http://dx.doi.org/10.1080/1331677X.2015.1041776

Bullen, C.; Rockart, J. 1981. A primer on critical success factors. Cambridge: Center for Information Systems Research, MIT Sloan School of Management.

Byrne, J. A. 1993. The horizontal corporation. Businessweek, New York: Bloomberg.

Dallavalle de Pádua, S. I.; Mascarenhas Hornos da Costa, J.; Segatto, M.; de Souza Júnior, M. A.; Jabbour Chiappetta, C. J. 2014. BPM for change management: two process diagnosis techniques, Business Process Management Journal 20(2): 247271. http://dx.doi.org/10.1108/BPMJ-03-2013-0039

Davenport, T. H.; Short, J. E. 1990. The new industrial engineering, Sloan Management Review 31(4): 1-31.

Filipowska, A.; Kaczmarek, M.; Kowalkiewicz, M.; Zhou, X.; Born, M. 2009. Procedure and guidelines for evaluation of BPM methodologies, Business Process Management Journal 15(3): 336-357. http://dx.doi.org/10.1108/14637150910960594

Gonçalves, R. 2010. Business process management as continuous improvement in business process, in $6^{\text {th }}$ International Scientific Conference Business and Management 2010, 13-14 May 2010, Vilnius, Lithuania.

Hammer, M.; Champy, J. 1993. Reengineering the corporation. New York: Harper Business.

Harmon, P. 2007. Business process change. A business process management guide for managers and process professionals. $3^{\text {rd }}$ ed. Waltham: Elsevier.

Harmon, P.; Wolf, C. 2014. The state of business process management. A BPTrends Report [online], [cited 08 February 2016]. Available from Internet: http://www.bptrends.com/bptrends-surveys/

Harmon, P.; Wolf, C. 2016. The state of business process management. A BPTrends Report [online], [cited 08 February 2016]. Available from Internet: http://www.bptrends.com/bptrends-surveys/

Humphrey, W. S. 1998. Characterizing the software process: a maturity framework, Software 5(2): 7379. http://dx.doi.org/10.1109/52.2014

Iqbal, N.; Nadeem, W.; Zaheer, A. 2015. Impact of BPR critical success factors on inter-organizational functions: an empirical study, The Business \& Management Review 6(1): 140-153.

Jeston, J.; Nelis, J. 2008. Business process management: practical guidelines to successful implementations. $2^{\text {nd }}$ ed. Burlington: Elsevier.

Jurczuk, A.; Gabryelczyk, R. 2015. Purposes of enterprises improvement in the context of process maturity, Scientific Papers of Silesian University of Technology, Organization and Management 83(1941): 245-254.

Karagiannis, D. 2013. Business process management: a holistic management approach, in H. C. Mayr, Ch. Kop, S. Liddle, A. Ginige. (Eds.). Information systems: methods, models and applications, Lecture Notes in Business Information Processing 137: $1-12$.

Kerremans, M. 2008. Maturity assessment for business process improvement leaders: six phases for successful bpm adoption. Stamford: Gartner.

Lee, R. G.; Dale, B. G. 1998. Business process management: a review and evaluation, Business Process Management Journal 4(3): 214-225. http://dx.doi.org/10.1108/14637159810224322

Looy van, A.; De Backer, M.; Poels, G. 2011. Defining business process maturity. A journey towards excellence, Total Quality Management 22(11): 1119-1137. http://dx.doi.org/10.1080/14783363.2011.624779

Malinova, M.; Hribar, B.; Mendling, J. 2014. A framework for assessing BPM success, in 22nd European Conference on Information Systems, 9-11 June 2014, Tel Aviv, Israel. Available from Internet:

http://aisel.aisnet.org/ecis2014/proceedings/track06/5/.

McCormack, K. 2001. Business process orientation: do you have it?, Quality Progress 34(1): 51-58. http://dx.doi.org/10.1201/9781420025569

McCormack, K. P.; Johnson, W. C. 2001. Business process orientation. Gaining the e-business competitive advantage. New York: St. Lucie Press. http://dx.doi.org/10.1201/9781420025569

McCormack, K.; Willems, J.; Van den Bergh, J.; Deschoolmeester, D.; Willaert, P.; Indihar Stemberger, M.; Bosilj Vuksic, V. 2009. A global investigation of key turning points in business process maturity, Business Process Management Journal 15(5): 792-815.

http://dx.doi.org/10.1108/14637150910987946 
Niehaves, B.; Poeppelbuss, J.; Plattfaut, R.; Becker, J. 2014. BPM capability development - a matter of contingencies, Business Process Management Journal 20(1): 90-106. http://dx.doi.org/10.1108/BPMJ-07-2012-0068

Nikolova-Alexieva, V. 2013. Process maturity analysis of the bulgarian enterprises, Procedia-Social and Behavioral Sciences 92: 632-636. http://dx.doi.org/10.1016/j.sbspro.2013.08.729

Object Management Group. 2008. Business process maturity model [online], [cited 08 February 2016]. Available from Internet: http://www.omg.org/spec/BPMM/

Ostroff, F. 1997. The horizontal organization. New York: Oxford University Press.

Pöppelbuß, J.; Röglinger, M. 2011. What makes a useful maturity model? A framework of general design principles for maturity models and its demonstration in business process management, in European Conference on Information Systems, 911 June 2001, Helsinki, Finalnd.

Pritchard, J. P.; Armistead, C. 1999. Business process management - lessons from European business, Business Process Management Journal 5(1): 10-15. http://dx.doi.org/10.1108/14637159910249144

Ravesteyn, P.; Batenburg, R. 2010. Surveying the critical success factors of BPM-systems implementation, Business Process Management Journal 16(3): 492-507. http://dx.doi.org/10.1108/14637151011049467

Röglinger, M.; Pöppelbuß, J.; Becker, J. 2012. Maturity models in business process management, Business Process Management Journal 18(2): 328-346. http://dx.doi.org/10.1108/14637151211225225

Rosemann, M.; de Bruin, T.; Power, B. 2008. BPM maturity, in Jeston, J.; Nelis, J. Business process management: practical guidelines for successful implementations. Oxford: Elsevier.

Safrudin, N.; Recker, J. 2012. A typology for business transformations, in J. Lamp (Ed.). Proceedings of the $23^{\text {rd }}$ Australasian Conference for Information Systems, 3-5 December 2012, Geelong, Australia.

Safrudin, N.; Rosemann, M.; J. Recker, M.; Genrich, A. 2014. Typology of business transformations, Business Transformation Journal 10: 24-41. Available from Internet:

https://www.bta-online.com/knowledge/360-journal/

Santos, H. R. M.; Valença, G. A.; Alves, C. F. 2015. Strategies for managing critical success factors of BPM initiatives, in B. B. Zarpelão, F. A. Baião, S. W. M. Siqueira, A. M. Magdaleno (Eds.). Brazilian public organizations: a qualitative empirical study, iSys-Revista Brasileira de Sistemas de Informação 8(1): 42-64.

Scheel von, H.; von Rosing, G.; Skurzak, K.; Hove, M. 2015. BPM and maturity models, in M. von Rosing, A. W. Scheer, H. von Scheel (Eds.). The com- plete business process handbook. Boston: Morgan Kaufmann.

Scheer, A.W.; Brabänder, E. 2010. The process of business process management, in J. vom Brocke, M. Rosemann (Eds.). Handbook on business process management 2. International handbooks on information systems. Berlin-Heidelberg: SpringerVerlag.

Škrinjar, R.; Trkman, P. 2013. Increasing process orientation with business process management: critical practices, International Journal of Information Management 33(1): 48-60. http://dx.doi.org/10.1016/j.ijinfomgt.2012.05.011

Tarhan, A.; Turetken, O.; Reijers, H. A. 2016. Business process maturity models: a systematic literature review, Information and Software Technology [online], [cited 11 March 2016]. Available from Internet: http://www.sciencedirect.com/science/ article/pii/S0950584916300015

Tranfield, D.; Denyer, D.; Smart, P. 2003. Towards a methodology for developing evidence - informed management knowledge by means of systematic review, British Journal of Management 14(3): 207 222. http://dx.doi.org/10.1111/1467-8551.00375

Trkman, P. 2010. The critical success factors of business process management, International Journal of Information Management 30: 125-134. http://dx.doi.org/10.1016/j.ijinfomgt.2009.07.003

Warner, M.; Edwards, V.; Polonsky, G.; Pucko, D.; Zhu, Y. 2005. Management in transitional economies: from the Berlin Wall to the Great Wall of China. Psychology Press.

Westphal, J. D.; Gulati, R.; Shortell, S. M. 1997. Customization or conformity? An institutional and network perspective on the content and consequences of TQM adoption, Administrative Science 42 (2): 366-394. http://dx.doi.org/10.2307/2393924

Willaert, P.; Van den Bergh, J.; Willems, J., Deschoolmeester, D. 2007. The process-oriented organisation: a holistic view developing a framework for business process orientation maturity, in A. Gustavo, P. Dadam, M. Rosemann (Eds.). Business process management. Berlin Heidelberg: Springer. http://dx.doi.org/10.1007/978-3-540-75183-0_1

Wong, W. P.; Ahmad, N. H.; Nasurdin, A. M.; Mohamad, M. N. 2014. The impact of external environmental on business process management and organizational performance, Service Business 8(4): 559-586. http://dx.doi.org/10.1007/s1 1628-013-0207-9

Zairi, M. 1997. Business process management: a boundaryless approach to modern competitiveness, Business Process Management Journal 3(1): 64-80. http://dx.doi.org/10.1108/14637159710161585

Zellner, G. 2011. A structured evaluation of business process improvement approaches, Business Process Management Journal 17(2): 203-237. http://dx.doi.org/10.1108/14637151111122329 